\title{
The role of cue novelty and dimension dominance in the discrimination shifts of retardates ${ }^{1}$
}

L. W. HEAL, R. T. GEORGE, and M. L. BRANSKY, George Peabody College and Clover Bottom Hospital, Nashville, Tenn. 37203

A two-stage procedure was used to investigate conditions that facilitate the tendency to shift attention from one dimension to another (from color to form) in a discrimination-learning situation. It appeared that attention in Stage 2 had at least three determinants: (1) dimension relevance of the Stage 1, (2) dimension dominance of the $S$, and (3) novelty of the cues.

It is of considerable theoretical and practical interest to establish the conditions under which an organism attends to one class of cues (e.g., the form class or the color class) rather than to another. In recent years, methodological advances with discrimination-transfer paradigms have prompted the renewed study of attention. The present study used such a paradigm to test the prediction that an $S$ would be more likely to attend to a dimension if (1) it had been relevant for the solution of the immediately preceding problem, (2) it was represented by new (novel) cues, and (3) it was his dominant dimension.

\section{SUBJECTS}

The Ss were 49 residents of Clover Bottom Hospital and School, all of whom had previously solved discrimination problems with the apparatus. The Binet IQ range was 36 to 67 , and the CA range was from 12 to 38 .

\section{APPARATUS}

A two-choice discrimination apparatus was fitted with small readouts that projected $2 \times 2$ in. symmetrical forms on $3 \times 4$ in. colored backgrounds. When pressure was applied to either cue, microswitches were tripped, immediately turning off the projectors and producing either a door-chime (correct) or a loud buzzer (incorrect). The presentation of stimuli and feedback was automated and programmed electronically. The cues are described in the note to Table 1.

Fig. 1. Per cent correct on Trials 1-5 of Stage 4. Solid lines show the performance of color-dominant groups and broken lines the performance of form-dominant groups. The smaller Ns are always associated with the color-dominant groups.

\section{PROCEDURE}

The procedure required two sessions, one for assessing the dimension dominance of the $S$ and another for administering treatments. At the beginning of each session, $E$ told the $S$ to try to ring the "ding-dong" on every trial in order to earn a nickel. She then administered treatments from an adjoining room. Each session involved a two-stage discrimination problem. For the sake of clarity, Stages 1 and 2 will denote the two stages of the dimension-dominance session, and Stages 3 and 4 will denote the two stages of the optional-shift session. Table 1 shows the general design and procedure for the four stages.

The optional-shift problem required $S$ first to learn a discrimination problem (Stage 3) for which color was relevant and form irrelevant (50\% relevant). For some Ss, this was the dominant and for some the nondominant dimension. After $\mathbf{S}$ met criterion on this problem, he was given Stage 4, for which the form cues, color cues, both, or neither ( 2 by 2 factorial design) were replaced by new cues on the same dimension(s). When old color cues were retained, their values were reversed, so that Stage 4 required, in every case, a


shift from the Stage 3 solution. The solution of Stage 4 was ambiguous in that the $S$ was rewarded for consistent selection of either one of the colors or one of the forms. The attention of $S$ was defined in terms of his performance on Stage $4 . S$ was said to perseverate in his attention if he chose the color solution and to shift attention if he chose the form solution. Cue counterbalancing was done in Stage 3, so that every $S$ had the same cues per se in Stage 4 regardless of his condition.

\section{RESULTS AND DISCUSSION} Training Data

These sophisticated Ss found training very easy (median errors were either zero or one) during Stages 1,2, and 4, which could be solved on the basis of either color or form. In Stage 3, the form-dominant S took significantly longer to reach criterion (mean trials to the last error $=15.63$ ) than did the color-dominant $S$ (mean $=4.06$, $\mathrm{U}=418, \quad \mathrm{z}=3.39, \quad \mathrm{p}<.001$. This difference presumably occurred because Stage 3 was the only one for which some groups had to ignore cues from a dominant dimension.

\section{Choice Data}

The performance of the eight treatment conditions for the first five Stage 4 trials is shown in Fig. 1. Performances for the reversal conditions (old colors) began at near-zero levels and rose to near-perfect levels by the third trial. Performances for the nonreversal conditions (new colors) began at chance and rose to near-perfect levels by the third trial. The fourth trial
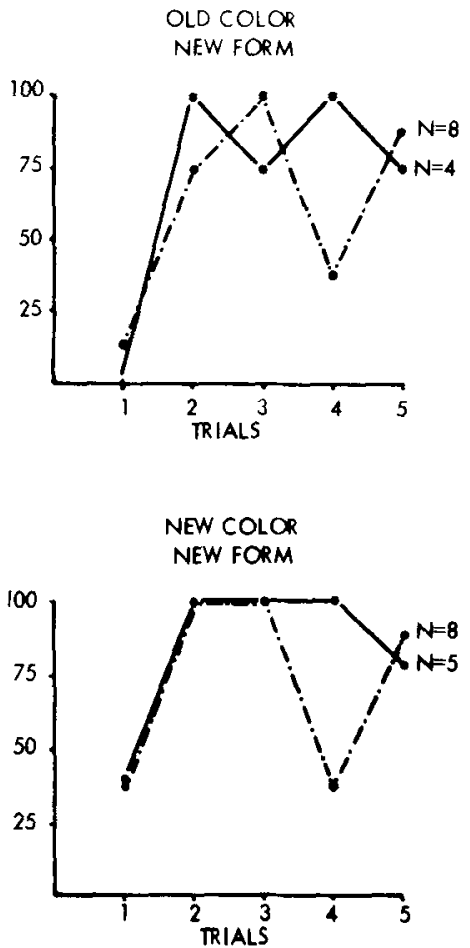
Table 1

Experimental Design

\begin{tabular}{|c|c|c|c|c|c|c|c|c|c|c|}
\hline \multirow{4}{*}{$\begin{array}{l}\text { Dimension } \\
\text { Dominance } \\
\text { Session }\end{array}$} & \multirow[b]{2}{*}{ Stage 1} & \multicolumn{2}{|c|}{$\begin{array}{l}\text { Old Colors } \\
\text { Old Forms } \\
\end{array}$} & \multicolumn{2}{|c|}{$\begin{array}{l}\text { Old Colors } \\
\text { New Forms }\end{array}$} & \multicolumn{2}{|c|}{$\begin{array}{l}\text { New Colors } \\
\text { Old Forms }\end{array}$} & \multicolumn{2}{|c|}{$\begin{array}{l}\text { New Colors } \\
\text { New Forms }\end{array}$} & \multirow[b]{2}{*}{$\begin{array}{l}\text { Criterion: } 8 \text { consecutive correct } \\
\text { Failure criterion: } 32 \text { trials }(\mathrm{N}=2)^{2}\end{array}$} \\
\hline & & $\stackrel{+}{\mathrm{C}_{1} \mathrm{~F}_{1}}$ & $\mathrm{C}_{2} \mathrm{~F}_{2}$ & $\stackrel{+}{\mathrm{C}_{1} \mathrm{~F}_{1}}$ & $\overrightarrow{\mathrm{C}}_{2} \overrightarrow{\mathrm{F}}_{2}$ & $\begin{array}{c}+ \\
\mathrm{C}_{1} \mathrm{~F}_{1} \\
\end{array}$ & $\mathrm{C}_{2} \bar{F}_{2}$ & $\begin{array}{r}+ \\
\mathrm{C}_{1} \mathrm{~F}_{1} \\
\end{array}$ & $\mathrm{C}_{2} \overline{\mathrm{F}}_{2}$ & \\
\hline & \multirow[t]{2}{*}{ Stag } & $\stackrel{+}{C_{1} F_{1}}$ & $\mathrm{C}_{2} \bar{F}_{2}$ & $\begin{array}{c}+ \\
\mathrm{C}_{1} \mathrm{~F}_{1} \\
\end{array}$ & $\mathrm{C}_{2} \bar{F}_{2}$ & $\mathrm{C}_{1} \mathrm{~F}_{1}$ & $\mathrm{C}_{2} \mathrm{~F}_{2}$ & $\begin{array}{r}+ \\
C_{1} F_{1} \\
\end{array}$ & $\mathrm{C}_{2} \overline{\mathrm{F}}_{2}$ & Trials $1,2,6$, and 9 \\
\hline & & $\begin{array}{c}+ \\
\mathrm{C}_{1} \mathrm{~F}_{2} \\
\end{array}$ & $\mathrm{C}_{2} \mathrm{~F}_{1}$ & $\begin{array}{c}+ \\
\mathrm{C}_{1} \mathrm{~F}_{2} \\
\end{array}$ & $\mathrm{C}_{2} \mathrm{~F}_{1}$ & $\begin{array}{c}+ \\
\mathrm{C}_{1} \mathrm{~F}_{2} \\
\end{array}$ & $\begin{array}{c}+ \\
\mathrm{C}_{2} \mathrm{~F}_{1} \\
\end{array}$ & $\begin{array}{c}+ \\
\mathrm{C}_{1} \mathrm{~F}_{2} \\
\end{array}$ & $\begin{array}{c}+ \\
\mathrm{C}_{2} \mathrm{~F}_{1} \\
\end{array}$ & $\begin{array}{l}\text { Failure criterion: } 3 \text { to } 5 \text { form } \\
\text { choices }(N=2) \\
\text { Trials } 3,4,5,7,8,10,11,12\end{array}$ \\
\hline \multirow{4}{*}{$\begin{array}{l}\text { Treatment } \\
\text { Session }\end{array}$} & $\begin{array}{l}\text { Stage } 3 \\
\text { (Original } \\
\text { Learning) }\end{array}$ & $\begin{array}{l}+ \\
\mathrm{C}_{6} \mathrm{~F}_{5} \\
+ \\
\mathrm{C}_{6} \mathrm{~F}_{6}\end{array}$ & $\begin{array}{c}- \\
\mathrm{C}_{5} \mathrm{~F}_{6} \\
- \\
\mathrm{C}_{5} \mathrm{~F}_{5}\end{array}$ & $\begin{array}{c}+ \\
\mathrm{C}_{6} \mathrm{~F}_{3} \\
+ \\
\mathrm{C}_{6} \mathrm{~F}_{4}\end{array}$ & $\begin{array}{l}\bar{C}_{5} \bar{F}_{4} \\
\overline{C_{5}} \bar{F}_{3}\end{array}$ & $\begin{array}{c}+ \\
\mathrm{C}_{3} \mathrm{~F}_{5} \\
+ \\
\mathrm{C}_{3} \mathrm{~F}_{6}\end{array}$ & $\begin{array}{c}- \\
\mathrm{C}_{4} \bar{F}_{6} \\
- \\
\mathrm{C}_{4} \bar{F}_{5}\end{array}$ & $\begin{array}{c}\stackrel{+}{\mathrm{C}_{3} \mathrm{~F}_{3}} \\
+ \\
\mathrm{C}_{3} \mathrm{~F}_{4}\end{array}$ & $\begin{array}{c}\overline{\mathrm{C}}_{4} \overline{\mathrm{F}}_{4} \\
\overline{\mathrm{C}_{4}} \\
\mathrm{~F}_{3}\end{array}$ & $\begin{array}{l}\text { Criterion: } 8 \text { consecutive correct } \\
\text { Failure criterion: } 32 \text { trials } \\
\text { (repeated after criterion on each } \\
\text { of two special training at tempts) } \\
(\mathrm{N}=1)\end{array}$ \\
\hline & $\begin{array}{l}\text { Special } \\
\text { Training }\end{array}$ & $\mathrm{C}_{6}^{+}$ & $\mathrm{C}_{5}^{+}$ & $\mathrm{C}_{6}^{+}$ & $\mathrm{C}_{5}^{+}$ & $\mathrm{C}_{3}^{+}$ & $\mathrm{C}_{4}^{+}$ & $\mathrm{C}_{3}^{+}$ & $\mathrm{C}_{4}^{+}$ & $\begin{array}{l}\text { Criterion: } 16 \text { consecutive correct } \\
\text { Failure criterion: 1st error after } \\
40 \text { th trial }\end{array}$ \\
\hline & \multirow{2}{*}{$\begin{array}{ll}\text { S } & \text { Shift } \\
+ & \text { Training } \\
\text { a } & \text { Trials } \\
\text { g } & \\
\text { e } & \text { Choice } \\
& \text { Trials } \\
\end{array}$} & $\stackrel{+}{\mathrm{C}_{5}} \mathrm{~F}_{5}$ & $\overline{\mathrm{C}}_{6} \overline{\mathrm{F}}_{6}$ & $\stackrel{+}{\mathrm{C}_{5} \mathrm{~F}_{5}}$ & $\bar{C}_{6} \bar{F}_{6}$ & $\stackrel{+}{\mathrm{C}_{5} \mathrm{~F}_{5}}$ & $\mathrm{C}_{6} \bar{F}_{6}$ & $\stackrel{+}{\mathrm{C}_{5} \mathrm{~F}_{5}}$ & $\overline{\mathrm{C}}_{6} \overline{\mathrm{F}}_{6}$ & $\begin{array}{l}\text { Trials } 1,2,3,5 \text {, etc. } \\
\text { Exactly } 13 \text { trials } \\
\text { Faijure criterion: } 4 \text { crrors on } \\
\text { Trials } 2-25(N=8)\end{array}$ \\
\hline & & $\stackrel{+}{\mathrm{C}_{5} \mathrm{~F}_{6}}$ & $\begin{array}{c}+ \\
\mathrm{C}_{6} \mathrm{~F}_{5} \\
\end{array}$ & $\stackrel{+}{\mathrm{C}_{5} \mathrm{~F}_{6}}$ & $\stackrel{+}{\mathrm{C}_{6} \mathrm{~F}_{5}}$ & $\begin{array}{c}+ \\
\mathrm{C}_{5} \mathrm{~F}_{6} \\
\end{array}$ & $\begin{array}{c}+ \\
\mathrm{C}_{6} \mathrm{~F}_{5} \\
\end{array}$ & $\stackrel{+}{\mathrm{C}_{5} \mathrm{~F}_{6}}$ & $\stackrel{+}{\mathrm{C}_{6} \mathrm{~F}_{5}}$ & $\begin{array}{l}\text { Trials } 4,6 \text {, etc. } \\
\text { Exactly } 12 \text { trials }\end{array}$ \\
\hline \multicolumn{2}{|c|}{$\begin{array}{l}\text { Number of form dominant } \\
\text { and coior dominant } \mathrm{Ss}\end{array}$} & \multicolumn{2}{|l|}{$\begin{array}{l}\mathrm{N}_{F}=9 \\
\mathrm{~N}_{\mathrm{C}}=3\end{array}$} & \multicolumn{2}{|l|}{$\begin{array}{l}N_{F}=8 \\
N_{C}=4\end{array}$} & \multicolumn{2}{|l|}{$\begin{array}{l}N_{F}=8 \\
N_{C}=4\end{array}$} & \multicolumn{2}{|c|}{$\begin{array}{l}\mathrm{NF}_{\mathrm{F}}=8 \\
\mathrm{NC}_{\mathrm{C}}=5\end{array}$} & \\
\hline $\begin{array}{ll}C_{1} & \text { Chartreuse } \\
C_{2} & \text { Burnt orange } \\
C_{3} & \text { Deep blue }\end{array}$ & & $\begin{array}{ll}C_{4} & P e a \\
C_{5} & B h \\
C_{6} & D e t\end{array}$ & $\begin{array}{l}\text { gray } \\
\text { ed }\end{array}$ & & & $\begin{array}{l}\text { Solid } \\
\text { Cross } \\
\text { Circle }\end{array}$ & $\begin{array}{l}\text { le } \\
\text { umser } \\
h 4 s u\end{array}$ & $\begin{array}{l}\text { d by a s } \\
\text { unding }\end{array}$ & & $\begin{array}{ll}F_{4} & X \\
F_{5} & \text { Square } \\
F_{6} & \text { A pair of vertical lines }\end{array}$ \\
\hline
\end{tabular}

was the first choice trial. A color choice was arbitrarily plotted as correct, although the $S$ was rewarded for either choice. Because color had been relevant for all conditions in Stage 2, "correct" choices on Trial 4 represented persisting attention, and "error" choices on Trial 4 represented shifting attention. Analyses based on all 12 choices did not change any of the conclusions reached below because of the marked bimodalitv of the 12-choice data.

Two results of the Stage 4 choice data seem noteworthy. First, a significant proportion of these Ss persisted in their attention to color in Stage 4 (37 of 49 , $\mathrm{p}<.01$ by a sign test). These data contrast with those of Sanders, Ross, \& Heal (1965), which suggested that retardates fail to persist in attending to a dimension when there is a shift in reward contingencies and/or a change in cues. Possibly the contrast can be attributed to the sophistication of the present Ss. That is, repeated discrimination training may establish a tendency to attend persistently to a particular dimension despite a change in reward or cues.

Second, two groups departed from the pattern of persisting attention to color. These were the two for which new cues were introduced on the form dimension for form-dominant Ss; a significant proportion $(10 / 16)$ of $\mathrm{Ss}$ in these conditions made attention shifts to these new cues. Fisher exact tests indicated that these new-forms by form-dominant conditions had more shifters $(10 / 16)$ than did either the new-forms by color-dominant conditions $(0 / 9$, Fisher exact $p \doteq .004)$ or the old-forms by form-dominant conditions (2/17, p $\doteq .006)$. Thus, considered separately, neither the introduction of novel cues nor dimension dominance was associated with a shift in the attention of the Ss. However, when these conditions occursed together, there was a significant shift in attention from the originally relevant dimension to the originally irrelevant.

In sum, these data suggest that retardates' tendency to shift attention from one class of cues to another is due, in part, to the relatively temporary effect of the reward and punishment associated with these classes of cues, in part to the relatively permanent predisposition to attend to certain classes of cues at the expense of others, and, in part, to the disposition to attend to novel cues. REFERENCES

SANDERS, B., ROSS, L. E., \& HEAL, L. W. Reversal and nonreversal shift learning in normal children and retardates of a comparable mental age. Journal of Experimental Psychology, 1965, 69, 84-88. NOTE

1. This research was supported in part by NIMH Grant MH 11371-01 and NICHD Grants HD-43 and HD-973. These data were reported at the annual meeting of the Southeast Section of the American Association on Mental Deficiency, October 1965, Nashville, Tenn. 